\title{
The Chondroitin Sulfate Proteoglycans Neurocan and Phosphacan Are Expressed by Reactive Astrocytes in the Chronic CNS Glial Scar
}

\author{
Robert J. McKeon, ${ }^{1}$ Michael J. Jurynec, ${ }^{2}$ and Charles R. Buck ${ }^{2}$ \\ Departments of ${ }^{1}$ Cell Biology and ${ }^{2}$ Physiology, Emory University School of Medicine, Atlanta, Georgia 30322
}

Chondroitin sulfate proteoglycans (CS-PGs) expressed by reactive astrocytes may contribute to the axon growth-inhibitory environment of the injured CNS. The specific potentially inhibitory CS-PGs present in areas of reactive gliosis, however, have yet to be thoroughly examined. In this study, we used immunohistochemistry, combined immunohistochemistry-in situ hybridization, immunoblot analysis, and reverse transcriptionPCR to examine the expression of specific CS-PGs by reactive astrocytes in an in vivo model of reactive gliosis: that is, the glial scar, after cortical injury. Neurocan and phosphacan can be localized to reactive astrocytes $30 \mathrm{~d}$ after CNS injury, whereas brevican and versican are not expressed in the chronic glial scar. Neurocan is also expressed by astrocytes in primary cell culture. Relative to the amount present in cultured astrocytes or uninjured cortex, neurocan expression increases significantly in the glial scar resulting from cortical injury, including the reexpression of the neonatal isoform of neurocan. In contrast, phosphacan protein levels are decreased in the glial scar compared with the uninjured brain. Because these CS-PGs are capable of inhibiting neurite outgrowth in vitro, our data suggest that phosphacan and neurocan in areas of reactive gliosis may contribute to axonal regenerative failure after CNS injury.

Key words: chondroitin sulfate proteoglycans; reactive astrocytes; glial scars; axonal regeneration; CNS injury; gene expression
The astrocytic response to CNS injury results in the formation of an "astroglial scar", which serves as a barrier to regenerating axons (Davies et al., 1999). However, CNS axons fail to regenerate past a lesion site, even in the absence of a recognizable glial scar (Davies et al., 1996), suggesting that reactive astrocytes establish a local biochemical rather than a purely physical barrier that inhibits significant axonal regeneration.

Chondroitin sulfate proteoglycans (CS-PGs) are present in areas of reactive gliosis after CNS injury to adult animals (McKeon et al., 1991; Bovolenta et al., 1993; Levine, 1994). Injury-induced CS-PGs inhibit neurite outgrowth in vitro, potentially by altering the properties of extracellular matrix (ECM) growth-promoting molecules (Dou and Levine, 1994, 1995; McKeon et al., 1995; Bovolenta et al., 1997). Thus, it is likely that CS-PGs have a profound effect on the ability of axons to regenerate in vivo through areas of reactive gliosis (Davies et al., 1997, 1999).

There is considerable heterogeneity of proteoglycan expression within the CNS (Herndon and Lander, 1990). The CNS-specific CS-PG core proteins brevican (Yamada et al., 1994) and phos-

\footnotetext{
Received May 25, 1999; revised Oct. 1, 1999; accepted Oct. 6, 1999.

This work was supported by Spinal Cord Research Foundation of the Paralyzed Veterans of America, National Institutes of Health Grant NS-35986, and the Office of the Dean of Research, Emory University. We thank Dr. Yu Yamaguchi (The Burnham Institute) and Dr. Richard LeBaron (University of Texas-San Antonio) for antibodies to specific CS-PGs and Anthony Frankfurter (University of Virginia) for the antibody to neuron-specific $\beta$-tubulin. Antibodies to neurocan (1F6) and phosphacan (3F8) were obtained from the Developmental Studies Hybridoma Bank maintained by the University of Iowa, Department of Biological Sciences, Iowa City, IA 52242. We thank Catherine Riley and Anne Mongiu for excellent technical assistance.

Correspondence should be addressed to Robert McKeon, Department of Cell Biology, Emory University School of Medicine, 1648 Pierce Drive, Atlanta, GA 30322-3030. E-mail: mckeon@cellbio.emory.edu.

Copyright (C) 1999 Society for Neuroscience 0270-6474/99/1910778-11\$05.00/0
}

phacan (Maeda et al., 1995) are expressed primarily by astrocytes (Meyer-Puttlitz et al., 1996; Yamada et al., 1997). The NG2 CS-PG is associated with O2A glial progenitor cells (Stallcup and Beasly, 1987) and may be required for oligodendrocyte differentiation (Nishiyama et al., 1996). Neurocan is another CS-PG distributed throughout the developing CNS (Meyer-Puttlitz et al., 1996). Although initially localized to neurons (Engel et al., 1996), neurocan is also expressed by cultured astrocytes (Oohira et al., 1994; Ascher et al., 1998).

NG2 mRNA and protein and phosphacan mRNA levels increase after CNS injury (Levine, 1994; Snyder et al., 1996), although the cell type responsible for the expression of these CS-PGs has not been determined. Because NG2 and phosphacan bind to cell and substrate adhesion molecules expressed in areas of reactive gliosis (Dou and Levine, 1994; Milev et al., 1994), these CS-PGs may inhibit axonal regeneration by binding to and restricting the availability of growth-promoting molecules. Although neurocan is also capable of inhibiting neurite outgrowth in vitro (Friedlander et al., 1994), the role of this CS-PG during axonal regenerative failure is not clear because changes in its expression after chronic brain injury have not been reported.

We have assessed the expression of specific CS-PGs in an in vivo model of chronic glial scarring induced by implanting a piece of nitrocellulose into the cerebral cortex of adult rats. Astrocytes infiltrate this implant and remain highly reactive, demonstrated by the continued expression of glial fibrillary acidic protein (GFAP) (McKeon et al., 1991). Thirty days after implantation, in situ hybridization (ISH) and immunohistochemistry (IHC) were used to localize specific CS-PG expression to reactive astrocytes in vivo. CS-PG mRNA or protein expression was also assessed in isolated glial scars by removing the implant from the cortex for reverse transcriptase (RT)-PCR or immunoblot analysis. CS-PG gene expression was compared between the isolated glial scar, 


\begin{tabular}{|c|c|c|c|c|}
\hline & Forward primer $5^{\prime} \rightarrow 3^{\prime}$ & Reverse primer $5^{\prime} \rightarrow 3^{\prime}$ & $\begin{array}{l}\text { Amplicon } \\
\text { size (bp) }\end{array}$ & Reference \\
\hline GAPDH & ATCACCATCTTCCAGGAGCG & TAGGAACACGGAAGGCCATG & 490 & Robbins and McKinney (1992) \\
\hline GFAP & CTCAATGCCGGCTTCAAAGAGA & GACGCAGCGTCTGTGAGGTC & 635 & Lewis et al. (1984) \\
\hline Neurofilament (M) & ACGCTGGACTCGCTGGGCAA & GCGAGCGCGCTGCGCTTGTA & 138 & Napolitano et al. (1987) \\
\hline Neurocan & СТGCTTCTTTACССТTCAАCСАC & AGTTGTCAAAGCCATCTTCGAAC & 443 & Rauch et al. (1992) \\
\hline Phosphacan & GAATTCTGGTCCACCAGCAG & GGTTTATACTGCCCTCTTTAGG & 496 & Maurel et al. (1994) \\
\hline
\end{tabular}

uninjured age-matched adult brain, and cultured astrocytes. Our results demonstrate that the expression of specific CS-PGs persists after cortical injury and that neurocan, particularly the neonatal isoform, is upregulated by reactive astrocytes.

\section{MATERIALS AND METHODS}

Filter implantation. Nitrocellulose filters (Millipore, Bedford, MA) were implanted into the cerebral cortex of 30-d-old Sprague Dawley rats according to the method of Rudge et al. (1989). Briefly, animals were anesthetized with rompun and ketamine ( $0.12 \mathrm{cc} / 100 \mathrm{gm}$, i.p.), a midline incision was made through the scalp, and the skin was retracted laterally. The periosteum was cleaned from the skull, and a rectangular window was drilled over each cerebral hemisphere, exposing the dura. An incision was then made in the cortex using a \#11 scalpel blade, and a $3 \times 3$ $\mathrm{mm}$ nitrocellulose filter (Millipore) was inserted. The craniotomy windows were covered with Gelfoam, and the skin was sutured closed. Animal care was in accordance with guidelines established by the Institutional Animal Care and Use Committee at Emory University.

Cell culture. Purified populations of neonatal cortical astrocytes were prepared according to standard methods (McCarthy and de Vellis, 1980). Newborn rat cerebral cortices were isolated free of adherent meninges, and the tissue was minced and incubated in HBSS containing $0.1 \%$ trypsin for $15 \mathrm{~min}$ at $37^{\circ} \mathrm{C}$. The tissue was dissociated into a single cell suspension by trituration through a fire-polished Pasteur pipette in the presence of $0.02 \%$ DNase. The cells were then pelleted by centrifugation, resuspended in DMEM-F-12 supplemented with $10 \%$ fetal calf serum, $2 \mathrm{~mm}$ glutamine, and $100 \mathrm{IU} / \mathrm{ml}$ penicillin-streptomycin, and seeded onto poly-L-lysine-coated tissue culture flasks. Cells were allowed to attach overnight and then were vigorously shaken to remove all loosely adherent cells: predominantly neurons, microglia, and oligodendrocytes. The remaining cells were allowed to grow to near confluence in DMEMF-12 supplemented with $10 \%$ FCS and 2 mM glutamine and were maintained at $37^{\circ} \mathrm{C}$ in $5 \% \quad \mathrm{CO}_{2}$. When nearly confluent, the cultures were passaged by incubating the cells in $0.1 \%$ trypsin and $0.02 \%$ EDTA for 10 min. Once the cells had lifted off the tissue culture dish, they were pelleted by centrifugation and resuspended in serum-containing media. The cultures were vigorously shaken the next day to remove loosely adherent cells, and the media was replaced. After passing each culture twice in this manner, immunocytochemical staining of representative cultures demonstrated that $>95 \%$ of the cells in these cultures were GFAP-immunopositive astrocytes, $<5 \%$ were OX-42-immunopositive microglia, $<1 \%$ were galactosyl cerebroside-immunopositive oligodendrocytes, and no neurons were detected using a neuron-specific TuJ1 antibody [generously provided by A. Frankfurter (University of Virginia, Charlottesville, VA)]. After a total of 1 month in vitro, all cultures were prepared for RNA isolation.

$R N A$ isolation. Total RNA was obtained from cultures of confluent astrocytes, from uninjured adult rat cerebral cortex, and from reactive astrocytes intimately associated with implanted nitrocellulose filters. To retrieve the implanted filter, animals were overdosed with chloral hydrate, the skull was removed, and the implant was located within the gray matter of the cerebral cortex. The implant was gently lifted from the brain, placed in $\mathrm{Ca}^{+2}$ - and $\mathrm{Mg}^{+2}$-free HBSS (Life Technologies, Gaithersburg, MD), and cleaned of any adherent or excess tissue to reduce the possibility of neuronal contamination. The implant was then placed into lysis buffer for RNA isolation. Tissue from the cerebral cortex of uninjured, age-matched control animals was harvested and placed directly into ice-cold RNA lysis buffer. Cultured astrocytes were lysed directly on the culture dish.

RNA was prepared as described by Chomczynski and Sacchi (1987).
Samples were lysed in $4 \mathrm{~m}$ guanidinium thiocyanate, followed by mixing with $2 \mathrm{~m}$ sodium acetate, $\mathrm{pH} 4$, phenol, and chloroform/isoamyl alcohol $(24: 1 \mathrm{v} / \mathrm{v})$. After two rounds of isopropanol precipitation, RNA was digested with RNase-free DNase I (Promega, Madison, WI) to eliminate DNA contamination. Purified RNA concentrations were determined with a spectrophotometer, and the integrity of the RNA was verified by denaturing agarose gel electrophoresis.

$R T-P C R$. One microgram of DNA-free RNA was subject to cDNA synthesis with random hexamer primers and SuperScript II reverse transcriptase (Life Technologies) for $1 \mathrm{hr}$ at $42^{\circ} \mathrm{C}$. Reverse transcriptase was inactivated, and RNA was degraded by boiling the reaction for 10 min (Freeman et al., 1994). One-tenth to one-hundredth of this reaction was directly added to the PCR reaction containing $50 \mathrm{~mm} \mathrm{NaCl}, 10 \mathrm{~mm}$ Tris-HCl, pH 9.0, $1.5 \mathrm{~mm} \mathrm{MgCl}_{2}, 0.1 \%$ Triton X-100, $0.2 \mathrm{~mm}$ dNTPs, 1 $\mu \mathrm{M}$ gene-specific primers, and $2 \mathrm{U}$ of Taq DNA polymerase (Promega). The primers used for the RT-PCR studies are indicated in Table 1. These primer sets specifically recognize only the genes of interest as indicated by amplification of a single band of the expected size and direct sequence analysis of the PCR product. In addition, comparison of the sequence of each primer and the resulting PCR product with the GenBank DNA sequence database using the basic local alignment search tool (BLAST) (Altschul et al., 1997) demonstrated that these sequences are unique to the gene of interest. Typical PCR reaction conditions were $20-35$ cycles of the following: $95^{\circ} \mathrm{C}$ for $30 \mathrm{sec}, 60^{\circ} \mathrm{C}$ for $30 \mathrm{sec}$, and $72^{\circ} \mathrm{C}$ for $120 \mathrm{sec}$, followed by a $5 \mathrm{~min}$ extension at $72^{\circ} \mathrm{C}$. Reactions were analyzed by electrophoresis in ethidium bromide containing agarose gels. Amplification of glyceraldehyde phosphate dehydrogenase (GAPDH), a relatively invariant internal reference RNA was performed in parallel, and cDNA amounts were standardized to equivalent GAPDH mRNA levels. Additional control experiments were performed to ensure that PCR reactions were sampled before the plateau phase of the amplification process. Varying quantities of starting RNA were subjected to RT-PCR to ensure that the amount of product was proportional to the amount of input RNA. PCR product specificity was confirmed by direct sequence analysis (Thermosequenase cycle sequencing kit; Amersham, Arlington Heights, IL). mRNA levels were further assessed by competitive RT-PCR using an internal competing template in the PCR reaction as described by Jin et al. (1994).

ISH. RT-PCR products were subcloned into pGEM-T (Promega) to enable synthesis of specific single-stranded digoxigenin (dig)-labeled RNA probes using dig-UTP RNA labeling mix (Boehringer Mannheim, Indianapolis, IN) and either T7 or SP6 RNA polymerase as described by the supplier. The in situ hybridization protocol was modified from Schaeren-Wiemers and Gerfin-Moser (1993) and Ma et al. (1997). Frozen sections $(10 \mu \mathrm{m})$ were obtained from brains harvested from either normal or filter-implanted animals perfused with $4 \%$ paraformaldehyde $30 \mathrm{~d}$ after implantation. Sections were thawed onto 3-aminopropyltriethoxy-silanecoated slides. Sections were permeabilized with proteinase $\mathrm{K}(1 \mu \mathrm{g} / \mathrm{ml})$ in $0.1 \mathrm{M}$ Tris- $\mathrm{HCl}$ and $50 \mathrm{~mm}$ EDTA, $\mathrm{pH} 8$, for $30 \mathrm{~min}$ at $37^{\circ} \mathrm{C}$, rinsed in $0.1 \mathrm{M}$ triethanolamine- $\mathrm{HCl}$, and acetylated in acetic anhydride $(0.25 \%$ $\mathrm{v} / \mathrm{v}$ ) and triethanolamine buffer for $10 \mathrm{~min}$, followed by a brief wash in $2 \times$ $\mathrm{SSC}(0.3 \mathrm{M} \mathrm{NaCl}$ and $30 \mathrm{~mm}$ sodium citrate, $\mathrm{pH}$ 7.0). Tissue sections were prehybridized for $4 \mathrm{hr}$ at $48^{\circ} \mathrm{C}$ in hybridization buffer $(50 \%$ formamide, $5 \times \mathrm{SSC}, 5 \mathrm{~mm}$ EDTA, $1 \times$ Denhardt's solution, $0.3 \mathrm{mg} / \mathrm{ml}$ yeast tRNA, $100 \mu \mathrm{g} / \mathrm{ml}$ heparin, and $0.1 \%$ Tween 20 ) and hybridized overnight at $48^{\circ} \mathrm{C}$ in the same buffer with dig-labeled probe $(1 \mu \mathrm{g} / \mathrm{ml})$. The sections were washed at $48^{\circ} \mathrm{C}$ in $1 \times \mathrm{SSC}$ for $10 \mathrm{~min}, 1.5 \times \mathrm{SSC}$ for $10 \mathrm{~min}$, at $37^{\circ} \mathrm{C}$ for in $2 \times$ SSC for $30 \mathrm{~min}$, and digested with $0.1 \mu \mathrm{g} / \mathrm{ml} \mathrm{RNase} \mathrm{in} 2 \times$ SSC at $37^{\circ} \mathrm{C}$ for $30 \mathrm{~min}$. Sections were rinsed in $2 \times \mathrm{SSC}$ for $10 \mathrm{~min}$, followed by a wash in $0.2 \times \mathrm{SSC}$ at $48^{\circ} \mathrm{C}$ for $1 \mathrm{hr}$. After equilibration in maleic acid buffer $(0.1 \mathrm{~m}$ maleic acid and $0.15 \mathrm{M} \mathrm{NaCl}, \mathrm{pH} 7.5$ for $5 \mathrm{~min})$, sections 
were blocked for $1 \mathrm{hr}$ at $22^{\circ} \mathrm{C}$ and incubated for $1 \mathrm{hr}$ with alkaline phosphatase-conjugated anti-digoxigenin Fab fragments (1:5000) in blocking buffer. For immunohistochemical localization of GFAP on the same sections, the anti-GFAP antibody (1:500; Accurate Chemicals, Westbury, NY) was added to the anti-digoxigenin solution, and the slides were incubated at $37^{\circ} \mathrm{C}$ for $1 \mathrm{hr}$. In situ hybridization (and combined ISH-IHC) slides were subsequently washed for $1 \mathrm{hr}$ in maleic acid buffer and developed $3 \mathrm{hr}$ to overnight in color development buffer $(0.1 \mathrm{M}$ Tris, $\mathrm{pH} 9.5,0.1 \mathrm{M} \mathrm{NaCl}, 50 \mathrm{~mm} \mathrm{MgCl}_{2}, 0.1 \%$ Tween $20,10 \%$ polyvinyl alcohol, $0.315 \mathrm{mg} / \mathrm{ml}$ nitroblue tetrozolium, and $0.175 \mathrm{mg} / \mathrm{ml}$ bromochloro-indoyl-phosphate), according to the manufactuer's protocol (Boehringer Mannheim). The color development reaction was terminated in neutralizing buffer; the slides were dehydrated through an ethanol series and coverslipped. For double ISH-IHC, before dehydration the slides were equilibrated in PBS, $\mathrm{pH} 7.3$, for $20 \mathrm{~min}$ and incubated in biotinylated secondary antibody, followed by avidin-Texas Red (as described below).

Specificity of the ISH signal was demonstrated by the following: RNase treatment of control sections before hybridization, omission of the cRNA probe, hybridization with an excess of unlabeled antisense probe, and hybridization with corresponding sense strand probe. Each of these controls eliminated the specific signal. Images were photographed on a Leitz (Wetzlar, Germany) Orthoplan 2 microscrope, digitized on a flatbed scanner, and imported into Adobe Photoshop (Adobe Systems, Mountain View, CA) for figure preparation.

$I H C$. Tissue sections were prepared as above, except brains were post-fixed for $4 \mathrm{hr}$ in paraformaldehyde and cryoprotected with $30 \%$ sucrose. For neurocan IHC, animals were perfused and post-fixed with $4 \%$ paraformaldehyde containing $15 \%$ picric acid, which improved signal intensity. Twelve micrometer sections were collected and, for CS-PG IHC, were treated with $0.1 \mathrm{U} / \mathrm{ml}$ chondroitinase ABC (Seikagaku Kogyo Co., Tokyo, Japan) in $0.1 \mathrm{M}$ Tris- $\mathrm{HCl}$ and $30 \mathrm{~mm}$ sodium acetate, $\mathrm{pH} 8.0$ $\left(\right.$ at $37^{\circ} \mathrm{C}$ ) for $1 \mathrm{hr}$. Sections were immunostained with the rabbit polyclonal antibody against GFAP (1:500; Accurate Chemicals) to identify reactive astrocytes. Antibodies to brevican (RB18, provided by Dr. Yu Yamaguchi), phosphacan [RPTP1, provided by Dr. Yu Yamaguchi (The Burnham Institute, La Jolla, CA); or 3F8 obtained from the Developmental Studies Hybridoma Bank, University of Iowa, Iowa City, IA], neurocan (1F6, obtained from the Developmental Studies Hybridoma Bank), or versican [provided by Dr. Richard LeBaron (University of Texas, San Antonio, TX)] were used to identify these specific CS-PGs. Sections were incubated in primary antibody in TBS, $\mathrm{pH} 7.5$, with $0.2 \%$ Triton X-100 and $1.0 \%$ BSA overnight at $4^{\circ} \mathrm{C}$, washed three times in TBS, and for single labeling, incubated in the appropriate biotin-conjugated secondary antibody in TBS with 3\% normal goat serum for $1 \mathrm{hr}$ at room temperature, followed by incubation in avidin-Texas Red. The sections were washed three times in TBS, coverslipped in Vectashield (Vector Laboratories, Burlingame, CA), and viewed with a Leitz Orthoplan 2 microscrope equipped with fluorescent optics and a narrow bandpass Texas Red filter cube. For double labeling, rhodamine-conjugated goat anti-rabbit and fluorescein-conjugated goat-anti mouse secondary antibodies were used. Negative controls included omitting the primary antibodies or, for double labeling, using the inappropriate secondary antibody, and were routinely negative. Images were acquired on a Zeiss (Oberkochen, Germany) laser scanning confocal microscope, model 510. Sequential scanning was used to excite and record the two fluorochromes independently. Images were imported into Adobe Photoshop for figure preparation.

Immunoblot analysis. Fourteen days after implantation, 10 filters were collected from adult animals, rinsed free of adherent tissue, homogenized with a dounce homogenizer in $100 \mu \mathrm{l}$ of buffer $\mathrm{H}(210 \mathrm{~mm}$ mannitol, $70 \mathrm{~mm}$ sucrose, $5 \mathrm{~mm}$ HEPES, $5 \mathrm{~mm} \mathrm{~K}$-EGTA, and $0.1 \%$ Triton X-100, pH 7.2) containing $5 \mu \mathrm{g} / \mathrm{ml}$ aprotinin, $0.5 \mu \mathrm{g} / \mathrm{ml}$ antipain, $0.1 \mu \mathrm{g} / \mathrm{ml}$ pepstatin $\mathrm{A}$, and $0.2 \mathrm{~mm}$ phenylmethylsulfonyl flouride, sonicated for $10 \mathrm{sec}$ and clarified by centrifugation at $7000 \times g$ for $60 \mathrm{sec}$. Protein concentration was determined with the bicinchoninic acid assay (Pierce, Rockford, IL), and gel aliquots were digested with chondroitinase $\mathrm{ABC}(0.1 \mathrm{U} / \mathrm{ml}$ in $100 \mathrm{~mm}$ Tris and $10 \mathrm{~mm}$ sodium acetate, $\mathrm{pH} 8.0$, at $37^{\circ} \mathrm{C}$ for $3 \mathrm{hr}$ ) before electrophoresis in a $4-15 \%$ gradient precast SDS-PAGE gel. Gels were electroblotted onto polyvinylidene difluoride membrane (Pierce), blocked overnight in $8 \%$ dried milk in Tris-buffered saline, and probed with an antibody to neurocan (1F6, 1:1000) or phosphacan $(3 \mathrm{~F} 8,1: 1000)$ in $5 \%$ bovine serum albumin at $4^{\circ} \mathrm{C}$ overnight. Equal protein loading was confirmed by quantification of total p42/44 mitogen-activated protein kinase (MAPK) on the same membrane as described by the supplier of the anti-MAPK antibody (1:1000; New England Biolabs, Beverly, MA). After washing and peroxidase-conjugated secondary antibody incubation, positive signal was visualized using chemiluminescense (Amersham) according to manufacturer's protocol. Protein prepared in an identical manner from cerebral cortex and skeletal muscle of uninjured age-matched control animals served as positive and negative controls, respectively. Phosphacan protein levels were determined by comparing the density of the phosphacan signal (in arbitrary densitometric units) with the signal for the relatively invariant protein p42/44 MAPK, using the IS-1000 image analysis system with IA-200 software (Alpha Innotech Corp.). The phosphacan/MAPK ratio was compared between uninjured cerebral cortex and glial scar filter implants on four separate immunoblots. For neurocan, the $130 \mathrm{kDa}$ fragment was expressed at similar levels in uninjured cerebral cortex and glial scar filter implants, and this fragment was used as a standard to determine the level of $245 \mathrm{kDa}$ neurocan in these tissues.

\section{RESULTS}

Chondroitin sulfate proteoglycan expression in areas of reactive gliosis after traumatic injury has generally been detected using antibodies to epitopes common to many CS-PGs before or after chondroitinase digestion, such as CS-56 or 3B3. In this study, we sought to identify whether mRNA and protein corresponding to specific CS-PG core proteins were differentially expressed after CNS injury in a well characterized model of glial scarring.

The CNS-specific CS-PG phosphacan is produced by alternative splicing of the gene that also encodes two isoforms of the receptor protein tyrosine phosphatase $\beta$ (RPTP- $\beta$ ) (Maurel et al., 1994). As a secreted CS-PG, phosphacan lacks the transmembrane and cytoplasmic domains of the RPTP- $\beta$ isoforms. One of the phosphacan antibodies used in this study (RPTP1) also recognizes both forms of RPTP- $\beta$, whereas the $3 \mathrm{~F} 8$ phosphacan antibody specifically recognizes only phosphacan and the fulllength RPTP- $\beta$ isoform (Fig. 1). To distinguish between phosphacan and the long form of RPTP- $\beta$, we designed RT-PCR primers and an in situ hybridization probe for phosphacan that detect only the mRNA encoding secreted phosphacan (Fig. 1). Different antibodies have been used to identify several forms of neurocan in the CNS (Meyer-Puttlitz et al., 1995). These include the 1F6 antibody, also used in this study, that recognizes a full-length $245 \mathrm{kDa}$ form of neurocan that predominates in neonatal brain and a $130 \mathrm{kDa} \mathrm{N}$-terminal proteolytic fragment that persists in the adult brain. The mRNA probe used in this study specifically recognizes the single transcript that encodes the fulllength and proteolytic fragments of neurocan (Fig. 1).

Increased GFAP immunoreactivity has been extensively used as a diagnostic feature of CNS reactive gliosis. Similarly, we used GFAP immunohistochemical staining to reveal the distribution of reactive astrocytes and for comparison with CS-PG-labeled cellular elements. As expected, GFAP immunoreactivity was significantly and chronically upregulated in astrocytic processes that grew within the filter implant $30 \mathrm{~d}$ after implantation (Figs. $2 C$, $3 C, D, 4 A)$.

\section{Phosphacan is expressed by reactive astrocytes after CNS injury}

In situ hybridization with riboprobes specific to phosphacan demonstrated the expression of this CS-PG on cellular processes that extended into the implanted filter $30 \mathrm{~d}$ after injury (Fig. 2A), consistent with previous reports of phosphacan mRNA expression after CNS injury (Snyder et al., 1996). Combined phosphacan in situ hybridization and GFAP immunohistochemistry demonstrates a consistent overlap of phosphacan mRNA with GFAP-immunopositive reactive astrocytes (Fig. 2A, insets), indicating that reactive astrocytes are a source of phosphacan in 

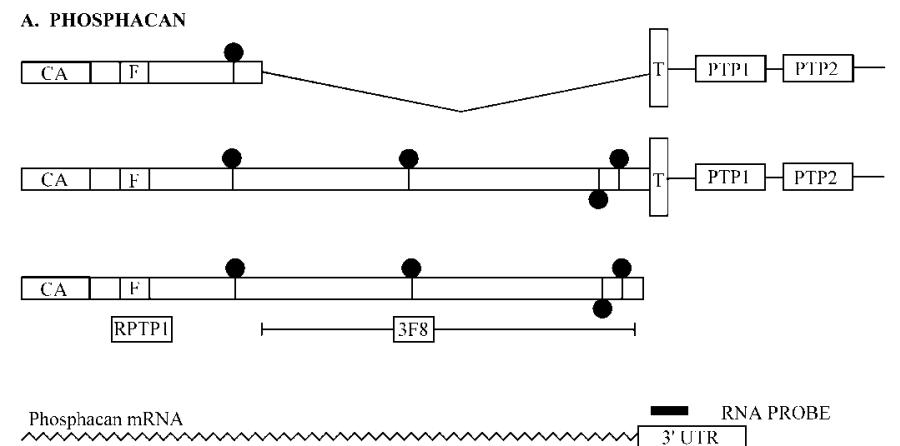

B. NELROCAN

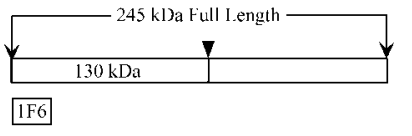

Neurocan mRNA

RNA PROBE

Figure 1. Schematic representation of phosphacan and neurocan to indicate location of epitopes and RNA probes used for immunohistochemistry and in situ hybridization. $A$, The three phosphacan protein isoforms are depicted as open rectangles. The RPTP1 antibody recognizes a site including the fibronectin type III repeat $(F)$ that is common to the RPTP $\beta$ short form (top), RPTP $\beta$ long form (middle), and secreted phosphacan (bottom). The 3F8 antibody recognizes a portion of the extracellular domain present in the RPTP $\beta$ long form and in secreted phosphacan but not in the RPTP $\beta$ short form. $C A$, Carbonic anhydrase domain; PTP, protein tyrosine phosphatase domains 1 and 2; $T$, transmembrane domain. Filled circles indicate consensus glycosaminoglycan attachment sites. The unique $3^{\prime}$ untranslated region (3'UTR) of the splice variant encoding phosphacan (phosphacan mRNA, jagged line) was selected for generating specific RT-PCR primers and riboprobes. $B$, The 1F6 antibody recognizes an $\mathrm{N}$-terminal epitope of neurocan. This epitope is contained in both the full-length $245 \mathrm{kDa}$ neurocan protein (neonatal form) and in a $130 \mathrm{kDa}$ proteolytic fragment that persists in adult animals. A unique $5^{\prime}$ region of the neurocan mRNA (jagged line) was used to generate specific RT-PCR primers and riboprobes. See Table 1 for specific sequences.

gliotic tissue. To further examine phosphacan expression by reactive astrocytes at the protein level, immunohistochemical staining was performed with two different phosphacan antibodies and with an anti-GFAP antiserum. Staining with the RPTP1 antiserum, which recognizes both phosphacan and RPTP- $\beta$, revealed heavily labeled processes projecting into the implant (Fig. $2 B$ ), similar to the pattern of phosphacan mRNA expression revealed by in situ hybridization. Higher magnification of sections double labeled with a monoclonal antibody (mAb) specific for phosphacan (3F8) and with anti-GFAP antiserum revealed a consistent overlap of each label on cells and processes around or projecting into the filter implant (Fig. $2 C$ ). These data provide evidence that phosphacan can be expressed by and is associated with reactive astrocytes after CNS injury and thereby contributes to the glial scar. Although the probe used for in situ hybridization is specific to phosphacan, the immunocytochemical data also support the possibility that reactive astrocytes express RPTP- $\beta$ after chronic injury.

\section{Neurocan is expressed by reactive astrocytes in vivo and by primary cultured astrocytes}

Although neurocan was originally described to be primarily of neuronal origin (Engel et al., 1996), other studies have demon- strated that this CS-PG can be expressed by astrocytes, at least in vitro (Oohira et al., 1994; Ascher et al., 1998). To confirm that reactive astrocytes can synthesize neurocan, we performed in situ hybridization for neurocan combined with GFAP immunohistochemistry on the same sections containing the glial scar filter implant. An antisense probe corresponding to a region near the $\mathrm{N}$ terminus of mature secreted neurocan revealed strong hybridization to cellular processes, which projected into the filter implants (Fig. $3 A, B)$. Immunohistochemistry with an anti-GFAP antiserum verifies that these are processes of reactive astrocytes. Moreover, the distribution of neurocan mRNA expression in cells surrounding the nitrocellulose filter implant overlapped with the distribution of GFAP-immunopositive cells and processes around and in the implant (Fig. 3C,D). We also used a monoclonal antibody (1F6) to neurocan to demonstrate that neurocan mRNA is translated into protein in cells that comprise the chronic glial scar (Fig. 3E). Thus, although the name implies that neurocan is expressed specifically by neurons (Engel et al., 1996), the distribution of neurocan expression we observed was strikingly similar to GFAP immunolabeling on the same section. This colocalization of neurocan mRNA and GFAP protein, along with the localization of neurocan protein on cellular processes within the implant, strongly suggests that reactive astrocytes of the glial scar secrete neurocan after chronic cortical injury. This conclusion is supported by RT-PCR and immunoblot analysis (Figs. 5, 6) demonstrating expression and synthesis of neurocan mRNA and protein by reactive astrocytes in vivo and by primary cultured astrocytes.

\section{The CNS proteoglycans brevican and versican do not localize to the glial scar}

To further explore CS-PG expression by reactive astrocytes, immunohistochemistry for two additional specific CS-PGs expressed in the CNS, brevican and versican, together with GFAP, was undertaken. Analysis of adjacent sections of injured cortex demonstrated a consistent expression of GFAP (Fig. 4A) but failed to reveal either brevican (Fig. 4B) and versican (Fig. 4C) staining, suggesting that, $30 \mathrm{~d}$ after implant, these proteoglycans were not expressed by reactive astrocytes. Consistent with our immunohistochemical data, in situ hybridization for brevican did not reveal detectable message levels for this CS-PG in glial scar tissue at this time point (data not shown). These results indicate that these proteoglycans are unlikely to contribute to the chronic glial scar. Moreover, reactive astrocytes apparently continue to selectively express some, but not other, CNS CS-PGs in the chronic glial scar (30 d after injury).

\section{CS-PG gene expression levels in the in vivo glial scar}

To further address the cell type specificity and to examine the relative levels of CS-PG gene expression in the glial scar, we used semiquantitative and quantitative RT-PCR. Approximately equivalent amounts of cDNA prepared from RNA from gliotic tissue formed in vivo, from intact age-matched cortex, and from primary cortical astrocyte cultures were determined by comparing the level of expression of the relatively invariant housekeeping gene GAPDH (Fig. 5). Amplification from standardized amounts of these cDNAs demonstrated a dramatic increase in GFAP mRNA levels in gliotic tissue formed in vivo compared with the uninjured rat cortex. Notably, the level of GFAP mRNA in the glial scar was also strongly elevated compared with primary astrocyte cultures, a frequently used in vitro model of glial scarring (Fig. 5). The steady-state level of neurocan mRNA was also 

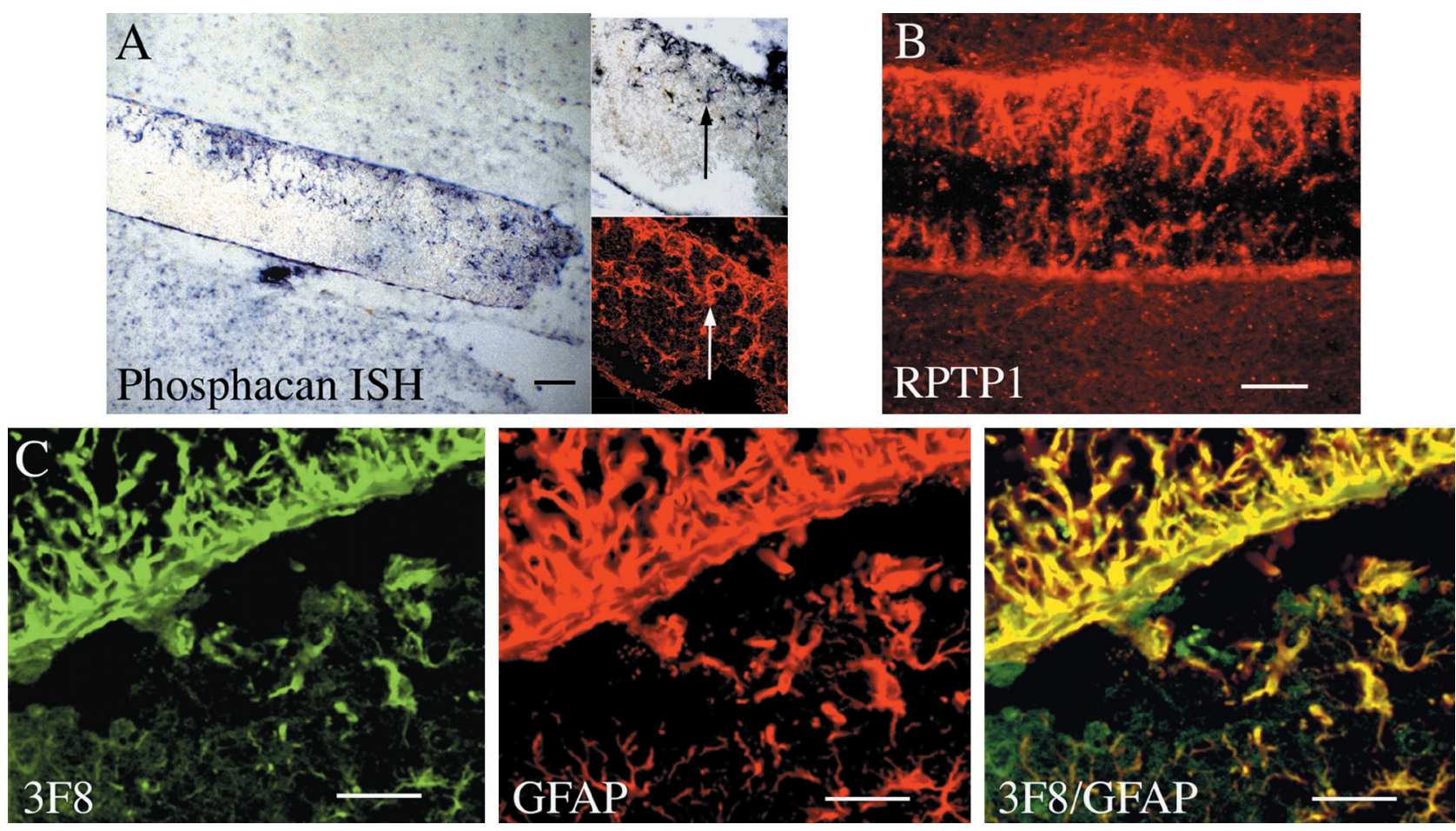

Figure 2. Phosphacan is expressed by reactive astrocytes in gliotic tissue. A, In situ hybridization with a digoxigenin-labeled antisense riboprobe indicates that phosphacan is synthesized by reactive astrocytes surrounding and penetrating the filter implant. The higher magnification insets indicate the coincidence of phosphacan mRNA (top) and GFAP (bottom) expression on the same section through the filter implant. The arrows indicate a phosphacan mRNA and GFAP containing reactive astrocyte cellular process. $B$, The anti-phosphacan antibody RPTP1 indicates that this CS-PG is expressed in the filter implant. $C$, To demonstrate the cell type specificity of phosphacan expression in the chronic glial scar, a second anti-phosphacan antibody, 3F8, and anti-GFAP were used for double immunohistochemistry and detected by confocal microscopy. Localization of phosphacan to reactive astrocytes is indicated by the extensive overlap of phosphacan and GFAP staining on cells surrounding the implant (arrowhead) and on processes that project into the implant (top left in all panels in $C$ ). Scale bar: $A, B, 50 \mu \mathrm{m} ; C, 20 \mu \mathrm{m}$.

elevated in both the filter implant and primary astrocyte cultures compared with the uninjured cortex (Fig. 5). In comparison, phosphacan mRNA was only slightly elevated in gliotic tissue collected from the implanted filter compared with the uninjured cortex and was barely detectable in cultured astrocytes (Fig. 5). Amplification of mRNA encoding the medium neurofilament subunit demonstrated expression of this neuron-specific gene in uninjured cortex but not in the filter implant or in primary astrocyte cultures. Immunohistochemical staining of sections containing a filter implant with an antibody to neuron-specific $\beta$-III tubulin (TuJ1) also demonstrated the absence of neuronal elements in this gliotic tissue in vivo (data not shown) (McKeon et al., 1997). Thus, neurons do not appear to contribute to the cellular infiltration of the filter implant and are unlikely to be the source of neurocan mRNA. Moreover, steady-state levels of the mRNA encoding the CS-PG neurocan are specifically elevated in glial scar tissue formed in vivo and in relatively pure cultures of cortical astrocytes, indicating that a specific response to injury by reactive astrocytes may be increased expression of this CS-PG.

The RT-PCR analysis was extended to obtain quantitative information about mRNA levels of specific CS-PGs expressed by cultured astrocytes, by reactive astrocytes associated with the filter implants after cortical injury, and by the uninjured cortex using competitive PCR as described by Jin et al. (1994). Consistent with the highly reactive nature of the tissue associated with the filter implants, GFAP mRNA is strongly elevated in the glial scar compared with uninjured rat cortex. GFAP mRNA levels in cultured astrocytes were similar to uninjured cortex. Phosphacan mRNA levels are relatively low in all three cDNA pools, with slightly higher levels in the glial scar than in uninjured cortex. In contrast, in glial scar tissue and in cultured astrocytes, neurocan expression is increased several-fold compared with uninjured cortex (Table 2).

\section{Immunoblot detection of specific CS-PGs in the glial scar}

Our in situ hybridization and RT-PCR data indicate that reactive astrocytes express neurocan and phosphacan mRNA, and immunohistochemical analysis indicates that these mRNAs are translated into protein. However, immunohistochemical detection of these and other extracellular matrix molecules can be difficult to interpret with certainty. To provide independent verification of specific CS-PG core protein expression in the in vivo glial scar, immunoblot analysis was performed with equal amounts of protein extracted from glial scar filters $14 \mathrm{~d}$ after implantation and from the cerebral cortex of uninjured age-matched control animals. Surprisingly, initial immunoblot analyses indicated that phosphacan protein levels were decreased in gliotic tissue. To verify this observation, we performed densitometric analysis of phosphacan protein levels, normalized to the level of the relatively invariant protein $\mathrm{p} 42 / 44 \mathrm{MAPK}$. The amount of phosphacan protein in the glial scar was decreased to $67 \pm 5.48 \%$ of the level present in the uninjured age-matched control cortex (Fig. 6A).

Alternatively, there is a dramatic increase in the amount of neurocan protein in gliotic tissue at $14 \mathrm{~d}$ after injury, consistent 

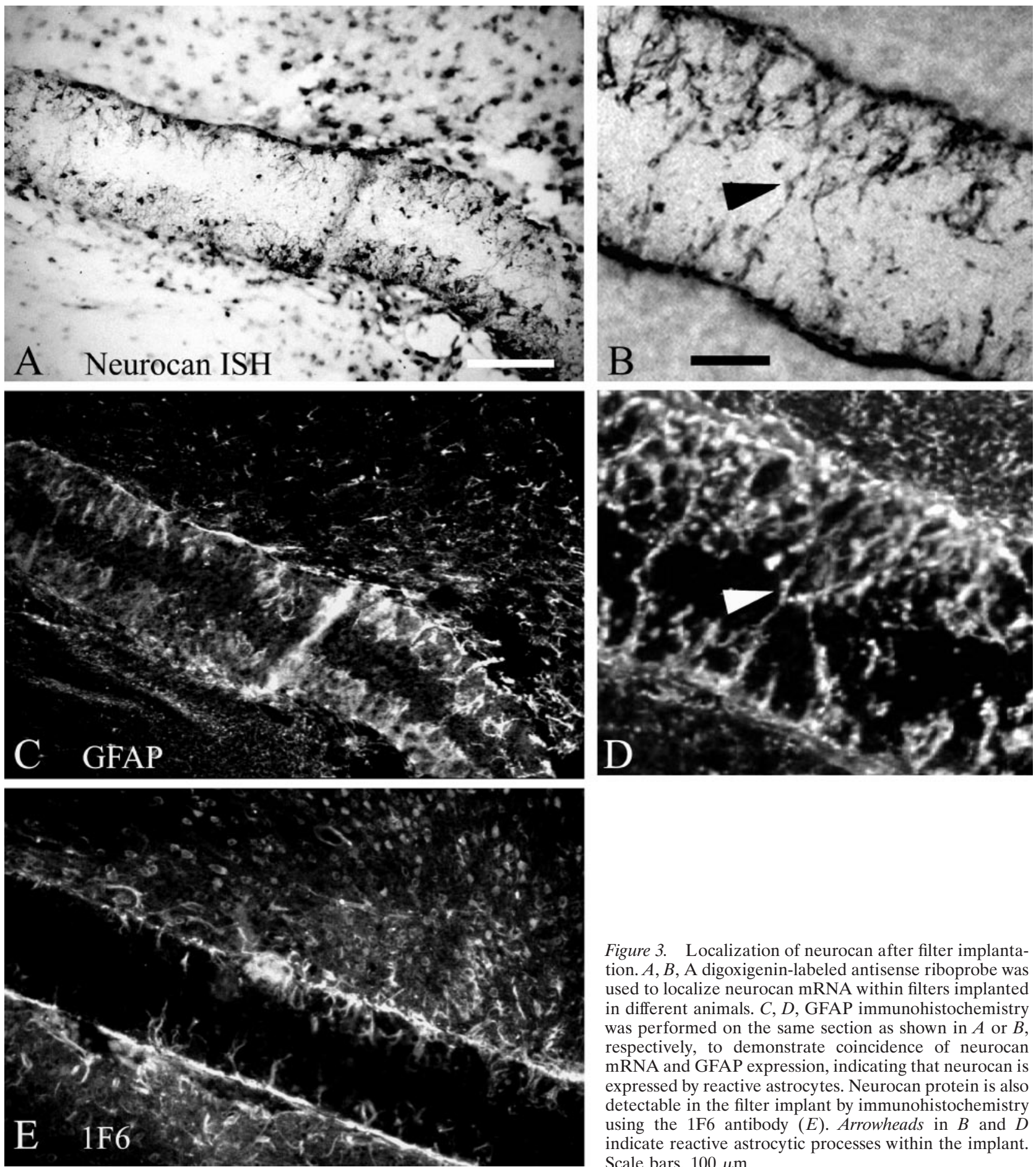

Figure 3. Localization of neurocan after filter implantation. $A, B$, A digoxigenin-labeled antisense riboprobe was used to localize neurocan mRNA within filters implanted in different animals. $C, D$, GFAP immunohistochemistry was performed on the same section as shown in $A$ or $B$, respectively, to demonstrate coincidence of neurocan mRNA and GFAP expression, indicating that neurocan is expressed by reactive astrocytes. Neurocan protein is also detectable in the filter implant by immunohistochemistry using the 1F6 antibody $(E)$. Arrowheads in $B$ and $D$ indicate reactive astrocytic processes within the implant. Scale bars, $100 \mu \mathrm{m}$.

with our mRNA analysis (Fig. 6B). In the uninjured age-matched cortex, the $130 \mathrm{kDa}$ neurocan proteolytic fragment predominates, with very little of the $245 \mathrm{kDa}$ developmentally regulated neonatal isoform apparent (Fig. 6B, lane 1), as reported previously (Meyer-Puttlitz et al., 1995). Interestingly, the neonatal isoform is increased $\sim 25$-fold in the injured brain (Fig. $6 \mathrm{~B}$, lane 2) compared with the normal cortex, whereas the amount of the $130 \mathrm{kDa}$ neurocan proteolytic fragment was not apparently different in the gliotic tissue and in the uninjured brain. In protein isolated from adult skeletal muscle, neither phosphacan nor neurocan protein is detected, as expected for these CNS-specific proteoglycans (Fig.
$6 A, B$, lane 3). Together with our immunocytochemical, in situ hybridization, and RT-PCR studies, these data confirm expression of phosphacan and neurocan in gliotic tissue and provide strong support for the hypothesis that these CS-PGs have a functional role in the astroglial response to adult brain injury.

\section{DISCUSSION}

The presence of a glial scar, formed in response to CNS injury, inhibits axonal regeneration (Davies et al., 1999). However, the putative inhibitory components of the glial scar have not been thoroughly elucidated. Previous studies have demonstrated that 

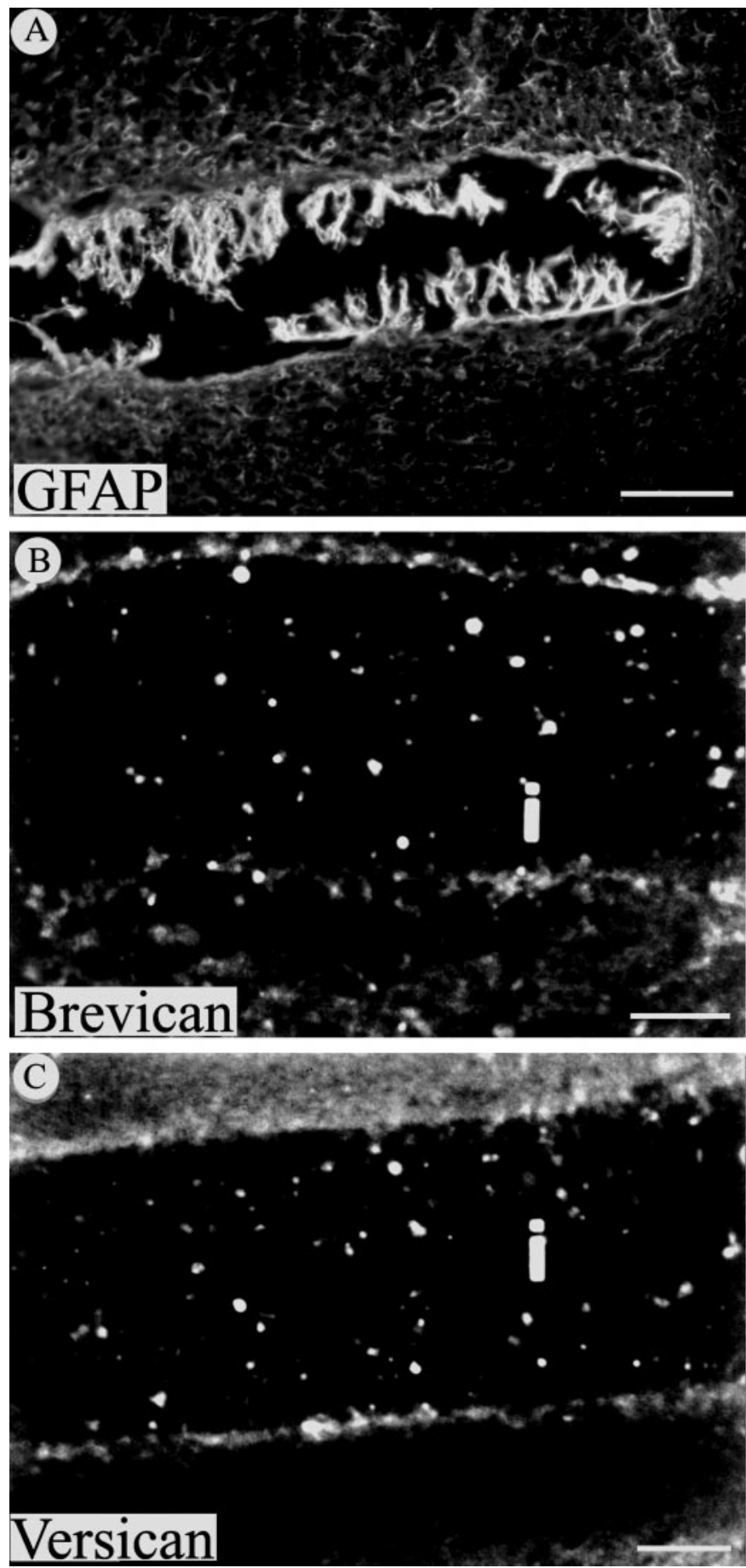

Figure 4. The CS-PG brevican and versican are not detected in the glial scar $30 \mathrm{~d}$ after injury. $A$, GFAP immunoreactivity is evident around the implanted filter and especially on astrocytic processes that extend into the implant. In contrast, immunohistochemistry for brevican $(B)$ and versican $(C)$ was negative at this same time point on sections from injured cortex containing filter implants $(i)$. Scale bars: $A, 100 \mu \mathrm{m} ; B, C, 50 \mu \mathrm{m}$.

CS-PGs are localized to the glial scar in vivo (McKeon et al., 1991; Bovolenta et al., 1997), and numerous in vitro studies indicate that CS-PGs can inhibit neurite outgrowth (Snow et al., 1990b, 1991; Oohira et al., 1991; Bovolenta et al., 1993; Guo et al., 1993; Zuo et al., 1998). In vitro differential adhesion assays indicate that, rather than simple neurite outgrowth promotion or inhibition, CS-PGs may contribute to progressively less adhesive gradients for neurite outgrowth during development (Emerling and Lander, 1996) and, potentially, to an anti-adhesive barrier to axon regrowth after CNS injury.

CS-PGs are a heterogeneous group of molecules with distinct core proteins. CS-PGs expressed within the CNS include neurocan and brevican, members of a major CS-PG subfamily that also includes aggrecan and versican, prominent CS-PGs from chondrocytes and fibroblasts, respectively (Yamada et al., 1994). Phosphacan is a distinct CNS CS-PG homologous to the extracellular domain of receptor-type protein tyrosine phosphatase- $\beta$ (Maurel et al., 1994).

Expression of CNS CS-PGs is generally highest during development and gradually decreases to basal adult levels during the first 2 postnatal weeks (Margolis and Margolis, 1993). It was initially suggested that CS-PGs may serve as axon growthinhibitory molecules because they are expressed in areas that serve as barriers to growing axons during development (Snow et al., 1990a). It has subsequently been demonstrated, however, that specific types of axons can grow through CS-PG-rich areas of the developing brain, indicating that these ECM molecules are more likely to modulate interactions between growing axons and the substrate, thereby helping segregate specific CNS pathways (Bicknese et al., 1994; Miller et al., 1995).

In vitro, neurocan, phosphacan, NG2, and brevican can inhibit neurite outgrowth from different populations of neurons (Dou and Levine, 1994; Friedlander et al., 1994; Milev et al., 1994; Maeda and Noda, 1996; Yamada et al., 1997; Garwood et al., 1999), consistent with in vivo studies implicating CS-PGs during axonal regenerative failure (McKeon et al., 1995; Bovolenta et al., 1997). Both NG2 and phosphacan mRNA increase after CNS injury, although the cell type responsible for the expression of these CS-PGs was not determined (Levine, 1994; Snyder et al., 1996). A nestin-positive subset of reactive astrocytes express the mRNA encoding the secreted isoform of brevican after stab wound injury to the adult rat CNS, but this mRNA returns to baseline within 2 weeks after injury (Jaworski et al., 1999). In the present study, we demonstrate that, at both the mRNA and protein levels, the putative axon growth-inhibitory CS-PGs neurocan and phosphacan are chronically expressed by reactive astrocytes after injury to the cerebral cortex. Alternatively, brevican and versican were not detected in the chronic cortical glial scar. Together, these data demonstrate that specific CS-PGs are produced by reactive astrocytes and support the hypothesis that certain CS-PGs may inhibit axonal regeneration after long-term CNS injury.

The underlying mechanisms whereby CS-PGs inhibit axonal regeneration are likely to be complex. For example, phosphacan is a secreted extracellular matrix molecule resulting from alternative splicing of the gene that also encodes RPTP- $\beta$ and a truncated RPTP- $\beta$ lacking an extracellular domain found in both full-length RPTP- $\beta$ and in phosphacan (Fig. 1A). Phosphacan binds to N-CAM and Ng-CAM and can inhibit neurite outgrowth, potentially by interfering with the interactions between these adhesion molecules and growing neurites (Milev et al., 1994). The short membrane-bound form of RPTP- $\beta$, however, interacts with Nr-CAM and contactin to promote neurite outgrowth (Sakurai et al., 1997). The RPTP1 antibody used in our studies was raised against an extracellular domain that included the fibronectin repeat common to phosphacan, full-length RPTP- $\beta$, and the truncated RPTP- $\beta$ isoform (Shitara et al., 1994). The second phosphacan antibody used for these studies, 

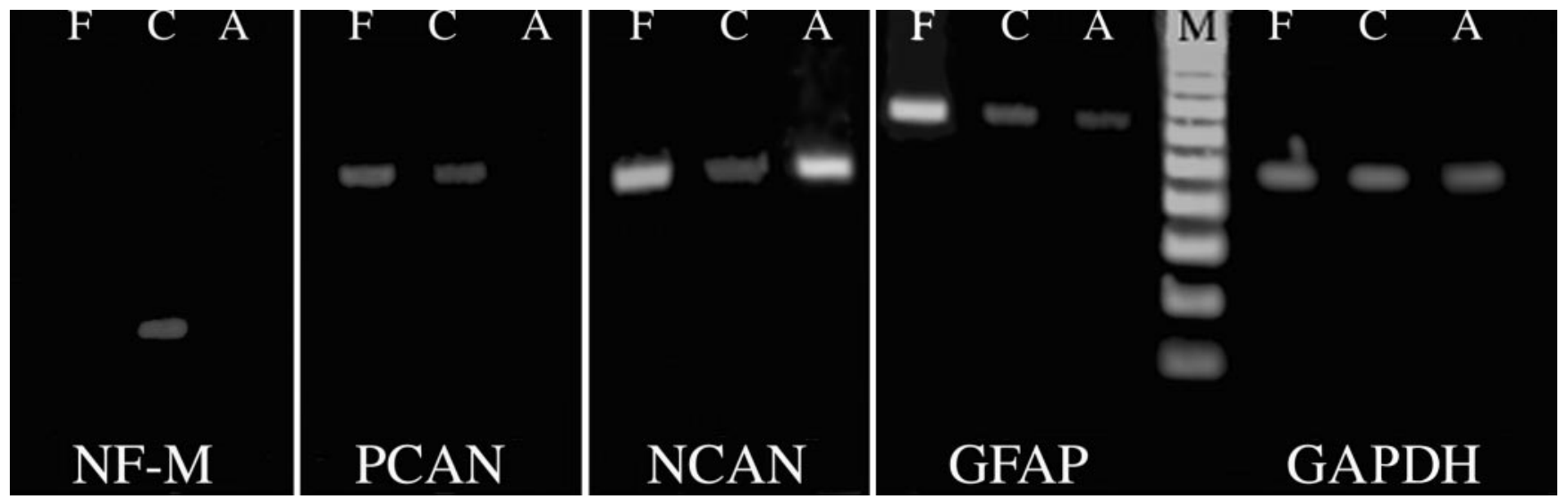

Figure 5. RT-PCR analysis of gene expression in the glial scar. cDNA prepared from implanted nitrocellulose filters $(F)$, uninjured adult rat cortex $(C)$, and primary astrocyte cultures $(A)$ was subjected to PCR amplification with gene-specific oligonucleotide primer pairs (see Table 1). Similar cDNA amounts were used in this analysis as indicated by the approximately equal amount of GAPDH amplification. Phosphacan mRNA is expressed in the filter implant at levels comparable with uninjured cortex. Neurocan mRNA levels are substantially elevated in the filter implant. The absence of neurofilament amplification in the filter implant supports the contention that this tissue does not include neuronal elements. GAPDH, Glyceraldehyde phosphate dehydrogenase (25 PCR cycles); GFAP, glial fibrillary acidic protein (25 PCR cycles); NCAN, neurocan (27 PCR cycles); PCAN, phosphacan (27 PCR cycles); $N F-M$, medium neurofilament subunit (29 cycles).

A

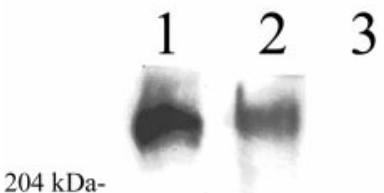

$120 \mathrm{kDa}-$

$47 \mathrm{kDa}-$

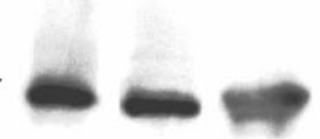

$204 \mathrm{kDa}-$

$120 \mathrm{kDa}-$

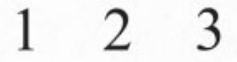

Figure 6. Immunoblot analysis of CS-PG expression in the glial scar. $A$, Levels of phosphacan protein in extracts prepared from gliotic tissue retrieved from filter implants (lane 2) are decreased to $\sim 67 \%$ of the levels in age-matched, uninjured cerebral cortex (lane 1), as detected with the 3F8 antibody. In this case, the phosphacan/MAPK values (in densitometric units) were $385,647 / 228,085$ (ratio of 1.6881) and 228,141/202,899 (ratio of 1.1244) for uninjured cortex and filter implant, respectively. $B$, The $130 \mathrm{kDa}$ proteolytic fragment of neurocan predominates in protein extracts from the cerebral cortex of uninjured age-matched control animals (lane 1), as detected using the 1F6 antibody to neurocan. Alternatively, in gliotic tissue retrieved from filter implants the full-length 245 $\mathrm{kDa}$ neonatal form of the neurocan protein is significantly upregulated (lane 2). In this case, the neurocan $245 \mathrm{kDa}$ /neurocan $130 \mathrm{kDa}$ values (see Materials and Methods) were 8454/378662 (ratio of 0.0223 ) and 284810/ 355734 (ratio of 0.8006) for uninjured cortex and filter implant, respectively. Neither phosphacan nor neurocan is detected in adult skeletal muscle ( $A$ and $B$, lane 3 ). For $A$ and $B, 30 \mu \mathrm{g}$ of protein were loaded in each lane.

$\mathrm{mAb} 3 \mathrm{~F} 8$, binds a region of the extracellular domain present only in full-length RPTP- $\beta$ and phosphacan. With immunohistochemistry and immunoblot analysis, we have detected specific labeling with both of these antibodies in reactive astrocytes and gliotic tissue. The possibility that phosphacan is selectively expressed is supported by our RNA data because only the mRNA encoding phosphacan is detected with our probes and this message is
Table 2. RT-PCR transcript levels in glial scar, uninjured cortex, and cultured astrocytes

\begin{tabular}{llcl} 
& $\begin{array}{l}\text { GFAP } \\
\text { mRNA }\end{array}$ & $\begin{array}{l}\text { Phosphacan } \\
\text { mRNA }\end{array}$ & $\begin{array}{l}\text { Neurocan } \\
\text { mRNA }\end{array}$ \\
\hline Glial scar implant & $\gg 50 \mathrm{fg}$ & $0.3 \mathrm{fg}$ & $2.5 \mathrm{fg}$ \\
Uninjured cortex & $25 \mathrm{fg}$ & $0.1 \mathrm{fg}$ & $0.3 \mathrm{fg}$ \\
Cultured astrocytes & $20 \mathrm{fg}$ & $<0.1 \mathrm{fg}$ & $3.5 \mathrm{fg}$
\end{tabular}

RT-PCR amplification from cDNA pools normalized to equivalent levels of GAPDH expression. The cDNA amplified for GFAP was produced from the equivalent of $5 \mathrm{ng}$ of total RNA. For phosphacan and neurocan, cDNA from the equivalent of $15 \mathrm{ng}$ of total RNA was used in the PCR reaction.

expressed in areas of reactive gliosis. Consistent with this, the phosphacan transcript is expressed at higher levels than either RPTP- $\beta$ transcript in adult brain (Sakurai et al., 1996). Although phosphacan protein levels are decreased in areas of chronic reactive gliosis, the presence of this protein in glial scars $30 \mathrm{~d}$ after CNS injury may influence interactions between neurons and injury-induced adhesion molecules. One effect may block neuronal binding to ECM components that could promote neurite outgrowth (Sakurai et al., 1997). Alternatively, phosphacan can promote neurite outgrowth from some types of neurons in vitro (Garwood et al., 1999). Relatively low phosphacan mRNA and protein levels in gliotic tissue may consequently result in an environment deficient in axon growth-permissive molecules relative to growth inhibitory ones. Thus, a specific function for phosphacan after CNS injury remains to be elucidated.

Neurocan binds to specific cell adhesion molecules and inhibits their ability to promote neurite outgrowth (Friedlander et al., 1994). We now demonstrate that neurocan mRNA and protein are present and specifically increased in areas of reactive gliosis after chronic CNS injury. Although initially described as a neuronal proteoglycan (Engel et al., 1996; Meyer-Puttlitz et al., 1996), recent studies have demonstrated that neurocan is synthesized by cultured astrocytes (Oohira et al., 1994; Ascher et al., 1998). Our RT-PCR data demonstrating the absence of neuronal contamination in the glial scar tissue used in these studies, together with the colocalization of neurocan mRNA and GFAP, indicate that 
neurocan expression is specifically localized to reactive astrocytes of the glial scar.

Several developmentally regulated forms of neurocan have been reported. Using the $1 \mathrm{~F} 6$ antibody, a $245 \mathrm{kDa}$ core protein abundant in the neonatal brain and a $130 \mathrm{kDa}$ proteolytic fragment that persists in the adult brain have been identified. Another neurocan antibody, 1D1, recognizes a $150 \mathrm{kDa}$ core protein predominant in the adult brain (Margolis and Margolis, 1993). Our immunoblot analysis with 1F6 demonstrates significant expression of the neonatal neurocan isoform in glial scars created in adult animals. Although the adult isoform has been detected in neonatal brain and we detect low levels of the neonatal isoform in uninjured adult brain, the re-expression of the neonatal neurocan isoform in injured adult brain has not been reported previously. Moreover, increased neurocan mRNA expression in the chronic glial scar revealed in our RT-PCR studies apparently results in a preferential increase in the neonatal form in this tissue because immunoblot analysis indicates that levels of the $130 \mathrm{kDa}$ fragment are similar in normal and injured brain. The significance of re-expression of the neonatal neurocan isoform is not clear but is consistent with reports that reactive astrocytes express specific developmentally regulated molecules (Clarke et al., 1994; Frisén et al., 1995). Although the specific mechanism whereby CNS injury induces CS-PG expression remains unknown, our data provide support for the hypothesis that expression of specific CS-PGs after injury may contribute to axonal regenerative failure.

Proteoglycan binding to growth factors may also modulate axonal regeneration. Both neurocan and phosphacan specifically bind to the neurite outgrowth-promoting factors amphoterin and pleiotrophin (Li et al., 1990; Hori et al., 1995; Maeda et al., 1996; Milev et al., 1998). Interestingly, pleiotrophin expression is increased by reactive astrocytes after acute CNS injury (Yeh et al., 1998). Neurocan or phosphacan secreted by reactive astrocytes may sequester these factors, thereby negating possible neurite growth-promoting effects.

In the present study, we show that neurocan and phosphacan are expressed in reactive astrocytes $30 \mathrm{~d}$ after a traumatic brain injury. The factor(s) regulating the expression of these individual CS-PGs is not known. The production of versican and aggrecan is elevated by transforming growth factor- $\beta$ (TGF- $\beta$ ) in fibroblasts and chondrocytes, respectively (Imai et al., 1994; Yaeger et al., 1997). Similarly, DSD-1-PG, the mouse homolog of phosphacan (Garwood et al., 1999), is expressed by immature glial cells in the developing CNS and is increased in vitro after exposure to TGF- $\beta$ (Schnädelbach et al., 1998). Recently, neurocan expression by cultured astrocytes has been reported to increase after exposure to TGF- $\beta$ (Ascher et al., 1998), consistent with our RT-PCR analysis of neurocan expression in vivo. Interestingly, temporal expression of CS-PGs in the developing CNS correlates with the expression of TGF- $\beta 2$ and $-\beta 3$, and these TGF- $\beta$ isoforms have been suggested to play a role in regulating the deposition of ECM molecules (Krieglstein et al., 1995). The expression of TGF- $\beta 1$ is limited in the developing brain but increases in areas of reactive gliosis associated with traumatic lesions, vascular infarcts, and senile plaques of Alzheimer's disease (Logan et al., 1992; van der Wal et al., 1993; Knuckey et al., 1996). The possibility that TGF- $\beta 1$ stimulates the expression of neurocan and phosphacan by reactive astrocytes after CNS injury is currently under investigation.

\section{REFERENCES}

Altschul SF, Madden TL, Schaffer AA, Zhang J, Zhang Z, Miller W, Lipman DJ (1997) Gapped BLAST and PSI-BLAST: a new generation of protein database search programs. Nucleic Acids Res 25:3389-3402.

Ascher RA, Fidler PS, Rogers, JH, Fawcett JW (1998) TGF- $\beta$ stimulates neurocan synthesis in cultured rat astrocytes. Soc Neurosci Abstr 24:56.

Bicknese AR, Sheppard AM, O'Leary DM, Pearlman AL (1994) Thalamocortical axons extend along a chondroitin sulfate proteoglycan-enriched pathway coincident with the neocortical subplate and distinct from the efferent path. J Neurosci 14:3500-3510.

Bovolenta P, Wandosell F, Nieto-Sampedro M (1993) Characterization of a neurite outgrowth inhibitor expressed after CNS injury. Eur J Neurosci 5:454-465.

Bovolenta P, Fernaud-Espinosa I, Méndez-Otero R, Nieto-Sampedro M (1997) Neurite outgrowth inhibitor of gliotic brain tissue. Mode of action and cellular localization, studied with specific monoclonal antibodies. Eur J Neurosci 9:977-989.

Chomczynski P, Sacchi N (1987) Single step method of RNA isolation by acid guanidinium thiocyanate-phenol-chloroform extraction. Anal Biochem 162:156-159.

Clarke SR, Shetty AK, Bradley JL, Turner DA (1994) Reactive astrocytes express the embryonic intermediate neurofilament nestin. NeuroReport 5:1885-1888.

Davies S, Field PM, Raisman G (1996) Regeneration of cut adult axons fails even in the presence of continuous aligned glial pathways. Exp Neurol 142:203-216.

Davies S, Fitch MT, Memberg SP, Hall AK, Raisman G, Silver J (1997) Regeneration of adult axons in white matter tracts of the central nervous system. Nature 390:680-683.

Davies SJA, Goucher, DR, Doller C, Silver J (1999) Robust regeneration of adult sensory axons in degenerating white matter of the adult rat spinal cord. J Neurosci 19:5810-5822.

Dou CL, Levine JM (1994) Inhibition of neurite growth by the NG2 chondroitin sulfate proteoglycan. J Neurosci 14:7616-7628.

Dou CL, Levine JM (1995) Differential effects of glycosaminoglycans on neurite growth on laminin and L1 substrates. J Neurosci 15:8053-8066.

Emerling DE, Lander AD (1996) Inhibitors and promoters of thalamic neuron adhesion and outgrowth in embryonic neocortex: functional association with chondroitin sulfate. Neuron 17:1089-1100.

Engel M, Maurel P, Margolis RU, Margolis RK (1996) Chondroitin sulfate proteoglycans in the developing central nervous system. I. Cellular sites of synthesis of neurocan and phosphacan. J Comp Neurol 366:34-43.

Freeman RS, Estus S, Johnson EM (1994) Analysis of cell cycle-related gene expression in postmitotic neurons: selective induction of cyclin D1 during programmed cell death. Neuron 12:343-355.

Friedlander D, Milev P, Karthikeyan, Margolis RK, Margolis RU, Grumet M (1994) The neuronal chondroitin sulfate proteoglycan neurocan binds to the neural cell adhesion molecules Ng-CAM/L1/NILE and N-CAM, and inhibits neuronal adhesion and neurite outgrowth. J Cell Biol 125:669-680.

Frisén J, Johansson CB, Török C, Risling M, Lendahl U (1995) Rapid, widespread, and long lasting induction of nestin contributes to the generation of glial scar tissue after CNS injury. J Cell Biol 131:453-464.

Garwood J, Schnädelbach O, Clement A, Schütte K, Bach A, Faissner A (1999) DSD-1-proteoglycan is the mouse homolog of phosphacan and displays opposing effects on neurite outgrowth dependent on neuronal lineage. J Neurosci 19:3888-3899.

Guo M, Dow KE, Kisilevsky R, Riopelle RJ (1993) Novel neurite growth-inhibitory properties of an astrocyte proteoglycan. J Chem Neuroanat 6:239-245.

Herndon ME, Lander AD (1990) A diverse set of developmentally regulated proteoglycans is expressed in the rat central nervous system. Neuron 4:949-961.

Hori O, Brett J, Slattery T, Cao R, Zhang J, Chen JX, Nagashima M, Lundh ER, Vijay S, Nitecki D, Morser J, Stern D, Schmitt A (1995) The receptor for advanced glycation end products (RAGE) is a cellular binding site for amphoterin. Mediation of neurite outgrowth and coexpression of rage and amphoterin in the developing nervous system. J Biol Chem 270:25752-25761.

Imai Y, Ibaraki K, Odajima R, Shishiba Y (1994) Analysis of proteoglycan synthesis by retro-ocular tissue fibroblasts under the influence of 
interleukin- $1 \beta$ and transforming growth factor- $\beta$. Eur $\mathrm{J}$ Endocrinol 131:630-638.

Jaworski DM, Kelly GM, Hockfield S (1999) Intracranial injury acutely induces the expression of the secreted isoform of the CNS-specific hyaluronan-binding protein BEHAB/brevican. Exp Neurol 157:327-337.

Jin C-F, Mata M, Fink DJ (1994) Rapid construction of deleted DNA fragments for use as internal standards in competitive PCR. PCR Methods Appl 3:252-255.

Knuckey NW, Finch P, Palm DE, Primiano MJ, Johanson CE, Flanders KC, Thompson NL (1996) Differential neuronal and astrocytic expression of transforming growth factor beta isoforms in rat hippocampus following transient forebrain ischemia. Mol Brain Res 40:1-14.

Krieglstein K, Rufer M, Suter-Crazzolara C, Unsicker K (1995) Neural functions of the transforming growth factors beta. Int J Dev Neurosci 13:301-315.

Levine JM (1994) Increased expression of the NG2 chondroitin-sulfate proteoglycan after brain injury. J Neurosci 14:4716-4730.

Lewis SA, Balcarek JM, Krek V, Shelanski M, Cowan NJ (1984) Sequence of a cDNA clone encoding mouse glial fibrillary acidic protein: structural conservation of intermediate filaments. Proc Natl Acad Sci USA 8:2743-2746.

Li Y-S, Milner PG, Chauhan AK, Watson MA, Hoffman RM, Kodner CM, Millbrandt J, Deuel TF (1990) Cloning and expression of a developmentally regulated protein that induces mitogenic and neurite outgrowth activity. Science 250:1690-1694.

Logan A, Frautschy SA, Gonzalez A-M, Sporn MB, Baird A (1992) Enhanced expression of transforming growth factor- $\beta 1$ in the rat brain after a localized cerebral injury. Brain Res 587:216-225.

Ma Q, Sommer L, Cserjesi P, Anderson DJ (1997) Mash1 and neurogenin1 expression patterns define complementary domains of neuroepithelium in the developing CNS and are correlated with regions expressing notch ligands. J Neurosci 17:3644-3652.

Maeda N, Noda M (1996) 6B4 proteoglycan/phosphacan is a repulsive substratum but promotes morphological differentiation of cortical neurons. Development 122:647-658.

Maeda N, Hamanaka H, Oohira A, Noda M (1995) Purification, characterization and developmental expression of a brain-specific chondroitin sulfate proteoglycan, 6B4 proteoglycan/phosphacan. Neuroscience 67:23-35.

Maeda N, Nishiwaki T, Shintani T, Hamanaka H, Noda M (1996) 6B4 proteoglycan/phosphacan, an extracellular variant of receptor-like protein-tyrosine phosphatase zeta/RPTPbeta, binds pleiotrophin/ heparin-binding growth-associated molecule (HB-GAM). J Biol Chem 271:21446-21452.

Margolis RK, Margolis RU (1993) Nervous tissue proteoglycans. Experientia 49:429-446.

Maurel P, Rauch U, Flad M, Margolis RK, Margolis RU (1994) Phosphacan, a chondroitin sulfate proteoglycan of the brain that interacts with neurons and neural cell-adhesion molecules, is an extracellular variant of a receptor-type protein tyrosine phosphatase. Proc Nat Acad Sci USA 91:2512-2516.

McCarthy KD, de Vellis J (1980) Preparation of separate astroglial and oligodendroglial cell cultures from rat cerebral tissue. J Cell Biol 85:890-902.

McKeon RJ, Schreiber RC, Rudge JS, Silver J (1991) Reduction of neurite outgrowth in a model of glial scarring is correlated with the expression of inhibitory molecules on reactive astrocytes. J Neurosci 11:3398-3411.

McKeon RJ, Höke A, Silver J (1995) Injury-induced proteoglycans inhibit the potential for laminin-mediated axon growth on astrocytic scars. Exp Neurol 136:32-43.

McKeon RJ, Silver J, Large TH (1997) Expression of full-length trkB receptors by reactive astrocytes after chronic CNS injury. Exp Neurol 148:558-567.

Meyer-Puttlitz B, Milev P, Junker E, Zimmer I, Margolis RU, Margolis RK (1995) Chondroitin sulfate and chondroitin/keratan sulfate proteoglycans of nervous tissue: developmental changes of neurocan and phosphacan. J Neurochem 65:2327-2337.

Meyer-Puttlitz B, Junker E, Margolis RU, Margolis RK (1996) Chondroitin sulfate proteoglycans in the developing central nervous system: Immunocytochemical localization of neurocan and phosphacan. J Comp Neurol 366:44-54.
Milev P, Friedlander DR, Sakurai T, Karthikeyan L, Flad M, Margolis RK, Grumet M, Margolis RU (1994) Interactions of the chondroitin sulfate proteoglycan phosphacan, the extracellular domain of a receptor-type protein tyrosine phosphatase, with neurons, glia, and neural cell adhesion molecules. J Cell Biol 127:1703-1715.

Milev P, Chiba A, Häring M, Rauvala H, Schachner M, Ranscht B, Margolis RK, Margolis RU (1998) High affinity binding and overlapping localization of neurocan and phosphacan protein-tyrosine phosphatase-zeta/beta with tenascin-R, amphoterin, and the heparinbinding growth-associated molecule. J Biol Chem 273:6998-7005.

Miller B, Sheppard AM, Bicknese AR, Pearlman AL (1995) Chondroitin sulfate proteoglycans the developing cerebral cortex: the distribution of neurocan distinguishes forming afferent and efferent axonal pathways. J Comp Neurol 355:615-628.

Napolitano EW, Chin SSM, Colman DR, Liem RKH (1987) Complete amino acid sequence and in vitro expression of rat NF-M, the middle molecular weight neurofilament protein. J Neurosci 7:2590-2599.

Nishiyama A, Lin XH, Giese N, Heldin CH, Stallcup WB (1996) Interaction between NG2 proteoglycan and PDGF alpha-receptor on O2A progenitor cells is required for optimal response to PDGF. J Neurosci Res 43:315-330.

Oohira A, Matsui F, Katoh-Semba R (1991) Inhibitory effects of brain chondroitin sulfate proteoglycans on neurite outgrowth from $\mathrm{PC} 12$ cells. J Neurosci 11:822-827.

Oohira A, Matsui F, Watanabe E, Kushima Y, Maeda M (1994) Developmentally regulated expression of a brain specific species of chondroitin sulfate proteoglycan, neurocan, identified with a monoclonal antibody $1 \mathrm{G} 2$ in the rat cerebrum. Neuroscience 60:145-157.

Rauch U, Karthikeyan L, Maurel P, Margolis RK, Margolis RU (1992) Cloning and primary structure of neurocan, a developmentally regulated, aggregating chondroitin sulfate proteoglycan of brain. J Biol Chem 267:19536-19547.

Robbins M, McKinney M (1992) Transcriptional regulation of neuromodulin (GAP-43) in mouse neuroblastoma clone N1E-115 as evaluated by the RT/PCR method. Mol Brain Res 13:83-92.

Rudge JS, Smith GM, Silver J (1989) An in vivo model of wound healing in the CNS: analysis of cell reaction and interaction at different ages. Exp Neurol 103:1-16.

Sakurai T, Friedlander DR, Grumet M (1996) Expression of polypeptide variants of receptor-type protein tyrosine phosphatase beta: the secreted form, phosphacan, increases dramatically during embryonic development and modulates glial cell behavior in vitro. J Neurosci Res 43:694-706.

Sakurai T, Lustig M, Nativ M, Hemperly JJ, Schlessinger J, Peles E, Grumet M (1997) Induction of neurite outgrowth through contactin and Nr-CAM by extracellular regions of glial receptor tyrosine phosphatase beta. J Cell Biol 136:907-918.

Schaeren-Wiemers N, Gerfin-Moser A (1993) A single protocol to detect transcripts of various types and expression levels in neural tissue and cultured cells: in situ hybridization using digoxigenin-labeled cRNA probes. Histochemistry 100:431-440.

Schnädelbach O, Mandl C, Faissner A (1998) Expression of DSD-1-PG in primary neural and glial-derived cell line cultures, upregulation by TGF-beta, and implications for cell- substrate interactions of the glial cell line oli-neu. Glia 23:99-119.

Shitara K, Yamada H, Watanabe K, Shimonaka M, Yamaguchi Y (1994) Brain-specific receptor-type protein-tyrosine phosphatase RPTP beta is a chondroitin sulfate proteoglycan in vivo. $\mathrm{J}$ Biol Chem 269:20189-20193.

Snow DM, Steindler DA, Silver J (1990a) Molecular and cellular characterization of the glial roof plate of the spinal cord and optic tectum: a possible role for proteoglycans in the development of an axon barrier. Dev Biol 138:359-376.

Snow DM, Lemmon V, Carrino DA, Caplan AI, Silver J (1990b) Sulfated proteoglycans in astroglial barriers inhibit neurite outgrowth in vitro. Exp Neurol 109:111-130.

Snow DM, Watanabe M, Letourneau PC, Silver J (1991) A chondroitin sulfate proteoglycan may influence the direction of retinal ganglion cell outgrowth. Development 113:1473-1485.

Snyder SE, Li J, Schauwecker PE, McNeill TH, Salton SRJ (1996) Comparison of $\mathrm{RPTPz} / \beta$, phosphacan, and trkB mRNA expression in the developing and adult rat nervous system and induction of RPTPz $/ \beta$ and phosphacan mRNA following brain injury. Mol Brain Res 40:79-96. 
Stallcup WB, Beasly L (1987) Bipotential glial precursor cells of the optic nerve express the NG2 proteoglycan. J Neurosci 7:2737-2744.

van der Wal EA, Gomez-Pinella F, Cotman C (1993) Transforming growth factor $\beta 1$ is in plaques in Alzheimer and Down pathologies. NeuroReport 4:69-72.

Yaeger PC, Masi TL, De OJ, Binette F, Tubo R, McPherson JM (1997) Synergistic action of transforming growth factor-beta and insulin-like growth factor-I induces expression of type II collagen and aggrecan genes in adult human articular chondrocytes. Exp Cell Res 237:318-325.

Yamada H, Watanabe K, Shimonaka M, Yamaguchi Y (1994) Molecular cloning of Brevican, a novel brain proteoglycan of the Aggrecan/ Versican family. J Biol Chem 269:10119-10126.
Yamada H, Fredette B, Shitara K, Hagihara K, Miura R, Ranscht B, Stallcup WB, Yamaguchi Y (1997) The brain chondroitin sulfate proteoglycan brevican associates with astrocytes ensheathing cerebellar glomeruli and inhibits neurite outgrowth from granule neurons. J Neurosci 17:7784-7795.

Yeh HJ, He YY, Xu J, Hsu CY, Deuel T (1998) Upregulation of pleiotrophin gene expression in developing microvasculature, macrophages, and astrocytes after acute ischemic brain injury. J Neurosci $18: 3699-3707$

Zuo J, Hernandez YJ, Muir D (1998) Chondroitin sulfate proteoglycan with neurite-inhibiting activity is up-regulated following peripheral nerve injury. J Neurobiol 34:41-54. 